\title{
Anti-Inflammatory Activity of Selected Edible Herbs and Spices on Cultured Human Gingival Fibroblasts
}

\author{
Shahida Mohd Said ${ }^{1,2, *}$, Fadzilah Adibah Abdul Majid ${ }^{3}$, Wan Aida Wan Mustapha ${ }^{4}$ and Ibrahim \\ $\operatorname{Jantan}^{2}$
}

${ }^{1}$ Faculty of Dentistry, Universiti Kebangsaan Malaysia, 50300 Kuala Lumupur; ${ }^{2}$ Faculty of Pharmacy, UKM; ${ }^{3}$ Faculty of Chemical Engineering, Universiti Teknologi Malaysia, Skudai; ${ }^{4}$ Faculty of Science and Technology, UKM, Bangi, Malaysia

\begin{abstract}
The aims of the study were to determine the in vitro cytotoxicity and anti-inflammatory activities of common edible herbs and spices on cultured human gingival fibroblasts (HGFs). Piper betle L. (betel leaf), P.sarmentosum Roxb. (wild betel / kadok leaf), P.nigrum L. (black pepper seed), Eugenia caryophyllata L. (clove bud) and Cinnamomum zeylanicum Blume (cinnamon bark). Essential oils were extracted using steam distillation technique and analysed using gas chromatography (GC) and gas chromatography - mass spectrometry (GC-MS). The HGFs were exposed to essential oils at $5-0.04 \mu \mathrm{g} / \mathrm{mL}$ in less than $1 \%$ dimethylsulfoxide and the number of viable cells was counted to assess cytotoxicity effect. Anti-inflammatory action was determined via the inhibitory action of Interleukin-6 (IL-6), a major proinflammatory cytokine in the periodontal tissue inflammation. Treatment of fibroblasts with essential oils resulted in $>$ $70 \%$ cell viability. The oils from black pepper seed, clove bud and cinnamon bark showed dose-dependent inhibitory action on IL-6 on cultured bacterial Lipopolysaccharide (LPS)-induced human gingival fibroblasts. Of all the oils, cinnamon bark oil showed the most prominent action comparable to acetylsalicylic acid. Conclusion: Essential oils of selected herbs and spices retained compatibility with gingival fibroblasts in culture and showed inhibitory activity on IL-6 released by LPS-induced HGFs. These findings suggest therapeutic potential for application of assay in the management of periodontal disease.
\end{abstract}

Keywords: Anti-inflammatory, periodontal, Piperaceae, Eugenia caryophyllata, Cinammomun zeylanicum.

\section{INTRODUCTION}

Periodontal disease remains as one of the common oral diseases worldwide and in Malaysia despite improvements and advancement in the oral health service $[1,2]$ Bacterialinfected mouth inevitably causes inflammation of the toothsupporting tissues, i.e. periodontal tissues, in a disease-prone individual. With this knowledge, disease management prioritise elimination of infective pathogens and inhibition of inflammation of the periodontium. However, the control of inflammation may take time and can be affected by many factors including access for treatment. Availability of overthe-counter and easy-to-apply anti-inflammatory agents that are evidence-supported would benefit the patients before they seek treatment at the dental clinic and may reduce the symptoms.

With current advancement of drug discovery research and safe traditional practices, medicinal herbs have been increasingly being studied for potential benefits including antibacterial and anti-inflammatory actions for use in dentistry [3-6]. Nevertheless, information is still scarce on the anti-inflammatory effect of common edible herbs and spices, namely:

*Address correspondence to this author at the Faculty of Dentistry, Universiti Kebangsaan Malaysia, 50300 Kuala Lumupur;

Tel: +60392897764; Fax: +603269829442;

E-mail: shahida@dental.ukm.my
- $\quad$ Piper betle L (betel, sireh), of Piperaceae family

- Piper sarmentosum Roxb. (wild betel, kadok)

- Piper nigrum L. (black pepper)

- Eugenia caryophyllata L. (clove, cengkih), Myrtaceae family

- Cinnamomum zeylanicum Blume (cinnamon, kayu manis), Lauraceae family on oral and periodontal tissues particularly.

The aims of this study were to determine (i) the cytotoxicity effect of selected herbal essential oils on cultured human gingival fibroblasts (HGFs) and (ii) the inhibitory effect of herbs on Interleukin-6 (IL-6) as the proinflammatory biomarker released by lipopolysaccharide (LPS)-induced HGFs.

\section{MATERIALS AND METHODS}

\section{Plant Materials and Sample Preparation}

Leaves of P.betle and P.sarmentosum were cleaned and air-dried in a ventilated room away from direct sunlight and with temperature between $26-30^{\circ} \mathrm{C}$ for 2 weeks. Leaves were then cut into small pieces while the spices (P.nigrum seeds, E.caryphyllata buds and C.zeylanicum tree bark) were grounded coarsely. Approximately $150 \mathrm{~g}$ of coarsely grounded herbal material were used for extraction of essential oils using the hydro-distillation technique for 8 
hours. The oily layers were separated and dried using anhydrous magnesium sulphate, purified through a modified wool filter and finally stored at $4{ }^{\circ} \mathrm{C}$ in air-tight bottles until use [7]. Moisture content was measured separately using the Dean's stalk and done in triplicates.

\section{Analyses of the Essential Oils}

Gas Chromatography (GC) analysis was used for identification of the essential oils components. The oil samples were dissolved in ethyl acetate and $0.1 \mu \mathrm{L}$ of each samples were injected in split mode into a Shimadzu GC2000 GC equipped with flame ionization detector (FID) detector and DB-5 column (1 $\mu \mathrm{m}$ thickness, $30.0 \mathrm{~m}$ length, $0.25 \mathrm{~mm}$ diameter). Nitrogen was the carrier gas used with a flow rate of $1.0 \mathrm{~mL} / \mathrm{min}$. The temperature of injector and detector were maintained at $250{ }^{\circ} \mathrm{C}$. Initial temperature of the oven was programmed at $75{ }^{\circ} \mathrm{C}$ for the initial $10 \mathrm{~min}$, then $3^{\circ} \mathrm{C} / \mathrm{min}$ to $230^{\circ} \mathrm{C}$ for $5 \mathrm{~min}$. Total program time was $73.33 \mathrm{~min}$ [8]. Subsequently, the essential oils were 'spiked' using the combined chromatography technique [9]. Using the same protocol as before, each essential oil sample was injected with a mixture of standard hydrocarbon series of $\mathrm{C}_{8}$ $-\mathrm{C}_{21}$. Location of each carbon series were identified based on the retention time of carbon series ran in the chromatogram earlier.

The essential oils were also examined using a Shimadzu QP5050A Gas Chromatography-Mass Spectrometry (GCMS) System, with HP-5MS column and held at stationary phase under controlled condition. The initial temperature of oven was set at $75^{\circ} \mathrm{C}$ for $5 \mathrm{~min}$, then maintained at $250^{\circ} \mathrm{C}$ for $10 \mathrm{~min}$. Helium was used as the carrier gas at $1.2 \mathrm{~mL} / \mathrm{min}$ air flow. Injector and detector temperature were maintained at $240-280{ }^{\circ} \mathrm{C}$.

\section{Qualitative Identification of Essential Oils Components}

All components of the essential oils were identified by comparing their retention indices based on Kováts index calculation [10] and GC-MS database library. Results were tabulated and compared.

\section{Human Gingival Fibroblast (HGF) Culture}

Primary cell culture explants of human gingival fibroblasts (HGF) were obtained from sound tooth extracted for orthodontics purposes. This protocol was in accordance to the requirements issued by the Research Ethics Committee of Universiti Kebangsaan Malaysia (UKM1.5.3.5/244/NF04-09) and modified from previous reported studies [11, 12]. Gingival tissues were scrapped off from the tooth surface using sterile blade and cultured in 6-well plates in Dulbecco's modified Eagle's medium (DMEM) supplemented with $10 \%$ foetal bovine serum (FBS), $1 \%$ Penicillin-Streptomycin and $1 \%$ fungizone (Amphotericin B). The explant was incubated in humidified atmosphere with $5 \% \mathrm{CO}_{2}$ at $37^{\circ} \mathrm{C}$ for 2 weeks. Growth medium was changed every 3 days. Once cells became $>75 \%$ confluent, cells were sub-cultured, stored and/or tested for assay. Cells passages between 3-10 were used in this study.

\section{Cell Viability Assay}

The viability of HGFs was determined using alamarBlue $^{\circledR}$ cell proliferation assay and techniques were modified from Unlu et al., 2010 [13]. Briefly, cells in serum- free growth medium were seeded at a density of $1 \times 10^{5}$ cells/well into 96-well microtitre plates for $24 \mathrm{~h}$. Main stocks of essential oils were dissolved in $100 \%$ dimethylsulfoxide (DMSO) at $500 \mathrm{mg} / \mathrm{mL}$ and then diluted in two-fold series to obtain eight serial dilutions. Each series were later mixed with serum-free medium to produce working series with concentrations ranging from $10-0.08 \mu \mathrm{g} / \mathrm{mL}$ and dispensed into well plates. For each $100 \mu \mathrm{L} /$ well of cell suspension, $100 \mu \mathrm{L}$ oil samples were added to give final concentrations of $5,2.5,1.25,0.63,0.31,0.13,0.08$ and $0.04 \mu \mathrm{g} / \mathrm{mL}$ in the reaction wells in triplicate copies. In addition, $20 \mu \mathrm{L}$ alamarBlue $^{\circledR}$ solution (Invitrogen Corp., U.S.A) was added to each well as a reagent for detecting cell viability. Wells with serum-free medium were referred as the blank wells, wells with oils samples as test wells and those seeded with HGFs in serum-free medium only were the negative control. Plates were incubated at $37^{\circ} \mathrm{C}$ with $5 \% \mathrm{CO}_{2}$ supply for $24 \mathrm{~h}$. Following incubation, absorbance was measured at $570 \mathrm{~nm}$ $\left(\mathrm{OD}_{570}\right)$ using a platereader (Thermo Scientific ${ }^{\circledR}$ Varioskan Flash Multimode Reader) the mean $\mathrm{OD}_{570}$ for each set of wells were calculated. The assay was repeated twice. Subsequently, the percentage of cell viability was calculated using the following formula:

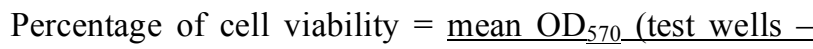
blank wells) x 100\%

mean $\mathrm{OD}_{570}$ (control wells - blank wells)

\section{Effective Inhibitory Concentration (IC)}

The percentage of cell growth inhibition was calculated (\% Inhibition $=100-$ viability $)$ and a dose-response curve was generated. Effectively, the half maximal inhibitory concentration, $\mathrm{IC}_{50}$, and $95 \%$ confidence interval were automatically calculated for each of oil samples by a nonlinear regression analysis using the GraphPad Prism version6 software (2012 GraphPad Software, Inc.).

\section{Induction and Treatment of HGFs}

For the anti-inflammatory assay modified from Zdařilová et al. (2009) [13], HGFs in serum-free growth medium were seeded at $1 \times 10^{5}$ cells/well in 96-well microtitre plates for 24h. Overnight-cultured HGFs were then induced with $1 \mu \mathrm{g} / \mathrm{mL}$ lipopolysaccharides from Escherichia coli 055:B5 (Sigma-Aldrich, U.S.A). After $4 \mathrm{~h}$ of incubation, the LPSinduced HGFs were then washed with PBS twice before exposed to oil sample mixtures in serum-free media. The final concentration of essential oils used for this assay was 1 , 5, 10 and $25 \mu \mathrm{g} / \mathrm{mL}$. Medium without any mixture of essential oils $(0 \mu \mathrm{g} / \mathrm{mL})$ was referred as the negative control while acetylsalicylic acid (Aspirin) was used as the positive control. Cells were incubated further for $4 \mathrm{~h}$ and the supernatant for each of the series were collected in microtubes and kept at $-20^{\circ} \mathrm{C}$.

\section{Quantification of IL-6}

The effect of E.caryophyllata and C.zeylanicum oils on IL-6 production by LPS-induced HGFs were determined using Enzyme-Linked Immunosorbent Assay (ELISA) kits according to the manufacturer's instructions (Invitrogen Corp., U.S.A) for detectable range between $500-2 \mathrm{pg} / \mathrm{mL}$. Briefly, culture supernatant was added to each well in duplicate copies and incubated for $2 \mathrm{~h}$ in room temperature 
Table 1. Constituents of Essential Oils.

\begin{tabular}{|c|c|c|c|c|c|}
\hline & $P b$ Leaf Oil & Ps Leaf Oil & Pn Seed Oil & Ec Flower Bud Oil & $E c$ Bark Oil \\
\hline $\begin{array}{c}\text { Total } \\
\text { compound } \\
\text { identified }\end{array}$ & 72 & 74 & 111 & 22 & 39 \\
\hline $\begin{array}{l}\text { Total amount } \\
\text { identified (\%) }\end{array}$ & 98.01 & 91.99 & 91.62 & 98.69 & 95.67 \\
\hline $\begin{array}{c}\text { Major } \\
\text { constituents } \\
\text { identified } \\
\text { (relative } \\
\text { amount in \%) }\end{array}$ & $\begin{array}{c}\beta \text { - bourbonene }(71.06)^{\mathrm{a}} \\
\text { Chavicol }(4.16)^{\mathrm{a}, \mathrm{b}} \\
\text { piperitone }(4.16)^{\mathrm{a}, \mathrm{b}} \\
E \text { - piperitol }(1.54)^{\mathrm{a}, \mathrm{b}} \\
Z \text { - } \beta \text { - farnesene }(1.24)^{\mathrm{a}, \mathrm{b}} \\
Z \text { - calamenene }(1.03)^{\mathrm{a}} \\
\gamma \text { - cadinene }(1.00)^{\mathrm{a}} \\
\delta \text { - cadinene }(1.00)^{\mathrm{a}}\end{array}$ & $\begin{array}{c}\text { Caryophyllene oxide } \\
\quad(26.22)^{\mathrm{a}, \mathrm{b}} \\
\alpha \text { - bisabolene }(26.22)^{\mathrm{a}, \mathrm{b}} \\
Z \text { - } \alpha \text { - bisabolene }(11.54)^{\mathrm{a}, \mathrm{b}} \\
\text { Aromadendrene }(7.68)^{\mathrm{a}, \mathrm{b}} \\
\delta \text { - cadinene }(2.90)^{\mathrm{a}} \\
\text { E- asarone }(2.68)^{\mathrm{a}, \mathrm{b}} \\
\text { Methyl eugenol }(2.36)^{\mathrm{a}, \mathrm{b}} \\
\alpha \text { - muurolene }(2.26)^{\mathrm{a}} \\
\alpha \text { - copaene }(2.08)^{\mathrm{a}, \mathrm{b}} \\
Z \text { - calamene }(1.08)^{\mathrm{a}} \\
Z \text { - pinane }(1.04)^{\mathrm{a}}\end{array}$ & $\begin{array}{c}\text { Limonene }(20.48)^{\mathrm{a}, \mathrm{b}} \\
\begin{array}{c}Z \text { - } \beta \text { - ocimene }(18.85) \\
\alpha \text {, b }\end{array} \\
\alpha \text { - humulene }(13.72)^{\mathrm{a}, \mathrm{b}} \\
\beta \text { - pinene }(11.16)^{\mathrm{a}, \mathrm{b}} \\
\alpha \text { - pinene }(5.92)^{\mathrm{a}, \mathrm{b}} \\
\text { Sabinene }(3.54)^{\mathrm{a}, \mathrm{b}} \\
\text { Cineole }<1,4->(2.53)^{\mathrm{a}} \\
\text { Myrcene }(2.33)^{\mathrm{a}, \mathrm{b}} \\
1,8 \text { - cineole }(1.66)^{\mathrm{a}, \mathrm{b}} \\
\beta \text { - elemene }(1.55)^{\mathrm{a}, \mathrm{b}}\end{array}$ & $\begin{array}{c}E \text { - methyl cinnamate } \\
(71.97)^{\mathrm{a}, \mathrm{b}} \\
\text { Eugenol acetate } \\
<\text { dihydro-> }(12.63)^{\mathrm{a}} \\
E \text { - isoeugenol }(11.72)^{\mathrm{a}, \mathrm{b}} \\
\gamma \text { - muurolene }(1.17)^{\mathrm{a}, \mathrm{b}}\end{array}$ & $\begin{array}{c}E \text { - cinnamaldehyde } \\
\quad(82.51)^{\mathrm{a}} \\
\alpha \text { - pinene }(1.40)^{\mathrm{a}, \mathrm{b}} \\
Z \text { - } \beta \text { - ocimene }(1.27)^{\mathrm{a}, \mathrm{b}} \\
\gamma \text { - terpineol }(1.09)^{\mathrm{a}, \mathrm{b}}\end{array}$ \\
\hline
\end{tabular}

Percentages of yield were calculated based on the concentrations obtained on GC column DB5 and retention index based on calculation of Kováts index; a constituents identified by $\mathrm{GC}, \mathrm{b}=$ constituents identified by GC-MS and database.



Fig. (1). Viability of HGFs after $24 \mathrm{~h}$ exposure to essential oils at various concentrations.

with specific biotinylated antibodies against the cytokines, followed by $30 \mathrm{~min}$ incubation with streptavidin-horseradish peroxidase. The plates were washed four times with phosphate buffer saline (PBS) between each incubation step. Stabilized chromogen was added in each well and incubated for further $30 \mathrm{~min}$ at room temperature and in the dark. Stop solution was added to each well and absorbance was measured at $450 \mathrm{~nm}$ wavelength using a platereader (Thermo Scientific ${ }^{\circledR}$ Varioskan Flash Multimode Reader). The amount of cytokine in each well was calculated using purified cytokine provided in the kit. A four parametric logistic curve fit for absorbance of the standard $\left(\mathrm{OD}_{450}\right)$ against the standard's mean concentrations $(\mathrm{pg} / \mathrm{mL})$ was generated using the curve fitting software (Thermo Scientific SkanIt ${ }^{\circledR}$ ) and finally the concentrations of IL-6 in the test samples were determined.

\section{RESULTS AND DISCUSSION}

The analyses of essential oils in this study identified approximately $91-98 \%$ of constituents in all oils tested. Total compounds identified were varied from 22 - 111 compounds (Table 1). Major constituents for each oil that were more than $1 \%$ are as listed. These findings were in concordance with those previously reported for P.betle [1417], P.sarmentosum [18-20], and P.nigrum [21], E.caryophyllata $[22,23]$ and C.zeylanicum $[8,12]$.

The use of essential oils on cultured HGFs showed high cell viability (mean $\geq 70 \%$ ) within $24 \mathrm{~h}$ treatment (Fig. 1). This suggests that all the essential oils are safe to be used on HGFs. 


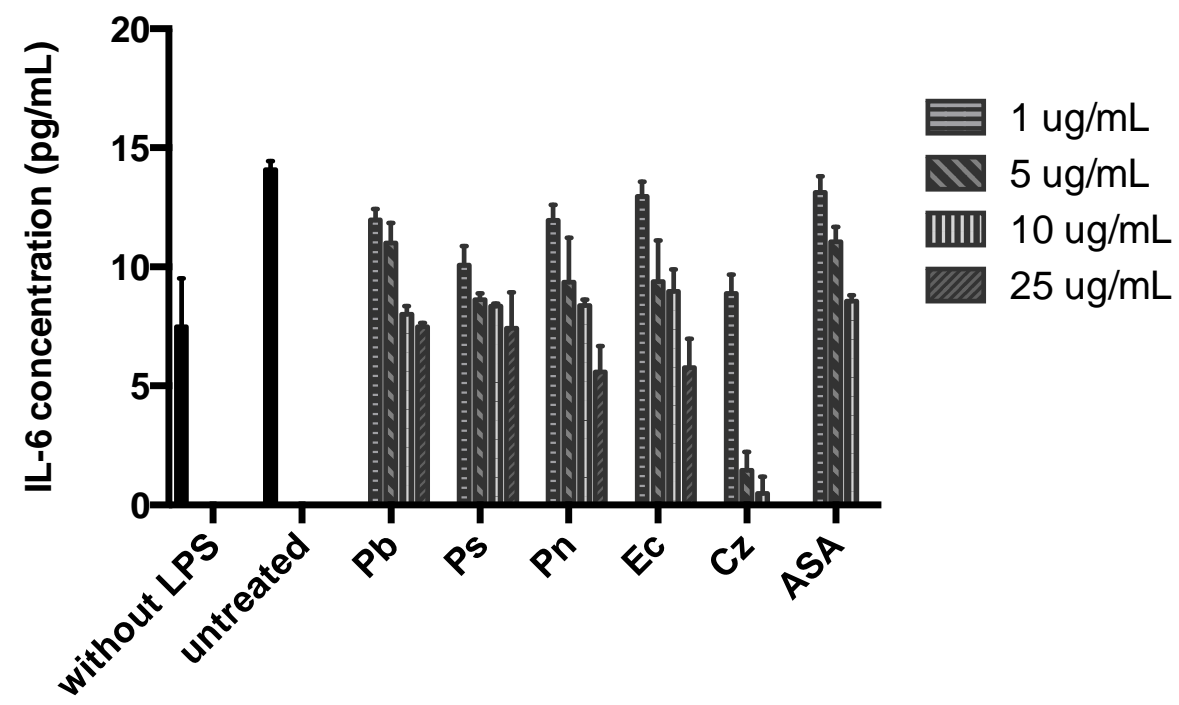

Fig. (2). Concentration of IL-6 produced by LPS-induced HGFs after 4h treatment with essential oils.

Table 2. Effectiveness of Essential Oils in Inhibition IL-6 Production by LPS-Induced HGFs

\begin{tabular}{|c|c|c|}
\hline Essential Oil & IC $_{\mathbf{5 0}}$ Value & $\mathbf{9 5 \%}$ CI \\
\hline \hline Piper betle & 27.03 & $13.55-53.94$ \\
\hline Piper sarmentosum & 30.78 & $11.98-79.07$ \\
\hline Piper nigrum & 14.78 & $9.23-23.68$ \\
\hline Eugenia caryophyllata & 16.43 & $10.00-27.00$ \\
\hline Cinnamomum zeylanicum & 1.38 & $1.18-1.61$ \\
\hline $\begin{array}{c}\text { Acetylsalicylic acid } \\
\text { (positive control) }\end{array}$ & 10.54 & $8.35-13.30$ \\
\hline
\end{tabular}

Values were calculated using GraphPad Prism (v6) software. $\mathrm{CI}=$ confidence interval.

$\mathrm{IC}_{50}$ concentration of oils that effectively inhibit $50 \%$ of the IL-6 production by cells, measured as mean $\mu \mathrm{g} / \mathrm{mL}$.

Following $4 \mathrm{~h}$ treatment to various concentrations of essential oils, the LPS-induced HGFs showed reduction in production of IL-6. Inhibitory action of all the essential oils and aspirin on IL-6 produced by treated LPS-induced HGFs was observed to be dose-dependent (Fig. 2).

Of all the essential oils used in the study, cinnamon bark oil showed the most prominent action compared to acetylsalicylic acid with the least $\mathrm{IC}_{50}$ value (Table 2). The other oils tested showed higher $\mathrm{IC}_{50}$ on HGFs compared to control, with values $>10 \mu \mathrm{g} / \mathrm{mL}$. The oils from the spices i.e. cinnamon, clove and black pepper seeds were found to be more effective in inhibiting IL-6 production compared to the oils from edible leaves of betel and wild betel.

The in-vitro anti-inflammatory activity in this study supported findings from previous studies [12, 24] More importantly, the relatively low cytotoxicity on cultured HGFs suggests that these oils are safe for use. In addition, the inhibition of IL-6 production by LPS-induced HGFs suggests beneficial property for future use in treating inflammed periodontal tissue.

\section{CONCLUSION}

Essential oils from edible herbs and spices namely betel leaf (P.betle), wild betel leaf (P.sarmentosum), black pepper seed (P.nigrum), clove bud (E.caryophyllata) and cinnamon bark (C.zeylanicum) showed low cytotoxicity on cultured HGFs and inhibited IL-6 released by lipopolysaccharide (LPS)-induced HGFs.

\section{CONFLICT OF INTEREST}

The authors confirm that this article content has no conflicts of interest.

\section{ACKNOWLEDGEMENT}

This project was supported by Universiti Kebangsaan Malaysia's Research University Grant (code UKM-GUPTKP-08-22-076).

\section{REFERENCES}

[1] Petersen, P. E.; Bourgeois, D.; Ogawa, H.; Estupinan-day, S.; Ndiaye, C. The global burden of oral diseases and risks to oral health. Bull. World. Health Organ., 2005, 83(9), 661-669.

[2] Ministry of Health Malaysia. Annual Report, 2009.

[3] Cowan, M.M. Plant products as antimicrobial agents. Clin. Microbiol. Rev., 1999, 12(4), 564-582.

[4] Perumal Samy, R.; Gopalakrishnakone, P. Therapeutic potential of plants as anti-microbials for drug discovery. Evid. Based Complement. Alternat. Med., 2010, 7 (3), 283-294.

[5] Palombo, E.A. Traditional medicinal plant extracts and natural products with activity against oral bacteria: potential application in 
the prevention and treatment of oral diseases. Evid. Based Complement. Alternat. Med., 2011, 2011, 680354.

[6] Groppo F. C.; Bergamaschi, C.; Cogo, K.; Franz-Montan, M.; Motta, R.H.L.; Andrade, E.E. Use of phytotherapy in dentistry. Phytother. Res., 2008, 22 (8): 993-998.

[7] Jantan, I. bin; Karim Moharam, B.A.; Santhanam, J.; Jamal, J.A. Correlation between chemical composition and antifungal activity of the essential oils of eight cinnamomum species. Pharm. Biol., 2008, 46(6), 406-412.

[8] Ahmad, F.; Moharm, B.A.; Jantan, I. A comparative study of the constituents of the essential oils of goniothalamus tapis miq. and $\mathrm{g}$. tapisoides mat salleh from borneo. J. Essent. Oil Res., 2010, 22(6), 499-502.

[9] McFadden, W.H. Techniques of Combined Gas Chromatography/Mass Spectrometry (Applications in Oraganis Analysis). New York: John Wiley and Sons 1973, p. 394.

[10] Kováts, E. Gas chromatographic characterization of organic substances in the retention index system. Adv. Chromatogr., 1965, (1 FG - 0), 229-247.

[11] Sonmez, S.; Kirilmaz, L.; Yucesoy, M.; Yücel, B.; Yilmaz, B. The effect of bee propolis on oral pathogens and human gingival fibroblasts. J. Ethnopharmacol., 2005, 102(3), 371-376.

[12] Unlu, M.; Ergene, E.; Unlu, G.V.; Zeytinoglu, H.S.; Vural, N. composition, antimicrobial activity and in vitro cytotoxicity of essential oil from cinnamomum zeylanicum blume (Lauraceae). Food Chem. Toxicol., 2010, 48(11), 3274-3280.

[13] Zdařilová, A.; Svobodová, A.; Šimánek, V.; Ulrichová, J. Prunella vulgaris extract and rosmarinic acid suppress lipopolysaccharideinduced alteration in human gingival fibroblasts. Toxicol. in vitro, 2009, 23(3), 386-392.

[14] Arambewela, L.; Kumaratunga, K. G.; Dias, K. Studies on piper betle of Sri Lanka. J. Nat. Sci. Found. Sri Lanka, 2005, 33(2), 133139.

[15] Caburian, A.B.; Osi, M. O. Characterization and evaluation of antimicrobial activity of the essential oil from the leaves of piper betle L. E-Int. Sci. Res. J., 2010, 2(1), 2-13.
[16] Kumar, R.; Singh, S.; Kulshresha, R.; Mishra, S.; Varshney, S.; Gupta, K. Volatile constituents of essential oil of betel leaf (Piper betle, Linn) Cv. Meetha. Indian Perfumer, 2007, 51(4), 55-58.

[17] Rimando, A.M.; Han, B.H.; Park, J.H.; Cantoria, M.C. Studies on the constituents of philippine piper betle leaves. Arch. Pharmacol. Res., 1986, 9(2), 93-97.

[18] Chieng, T.; Assim, Z. B.; Fasihuddin, B.A. Toxicity and antitermite activities of the essential oils from piper sarmentosum. Malay. J. Anal. Sci., 2008, 12(1), 234-239.

[19] Kawaree, R.; Phutdhawong, W.; Picha, P.; Ngamkham.; Chowwanapoonpohn, S. Chemical compounds, anticancer and antioxidant activities of volatile oil from piper sarmentosum roxb. polyscias fruticosa harms . and polygonum odoratun lour. KMITL International Conference on Science and Applied Sceince; 8-10 March 2006. Bangkok: Thailand 2006, (vol. 3, pp. 1-7).

[20] Qin, W.; Huang, S.; Li, C.; Chen, S.; Peng, Z. Biological activity of the essential oil from the leaves of piper sarmentosum roxb. (Piperaceae) and its Chemical Constituents on Brontispa longissima (Gestro) (Coleoptera:Hispidae). Pestic. Biochem. Physiol., 2010, 96, 132-139.

[21] Liu, L.; Song, G.; Hu, Y. GC - MS Analysis of the Essential Oils of Piper nigrum L. and Piper longum L. Chromatographia, 2007, 66(9), 785-790.

[22] Nassar, M.I.; Gaara, A.H.; El-Ghorab, A. H.; Farrag, A.-R. H.; Shen, H.; Huq, E.; Mabry, T.J. Chemical constituents of clove (syzygium aromaticum, fam . myrtaceae) and their antioxidant activity. Rev. Latinoamer. Quim, 2007, 35(3), 47-57.

[23] Prashar, A.; Locke, I.C.; Evans, C.S. (cytotoxicity of clove (syzygium aromaticum) oil and its major components to human skin cells. Cell Prolif., 2006, 39(4), 241-248.

[24] Mueller, M.; Hobiger, S.; Jungbauer, A. Anti-inflammatory activity of extracts from fruits, herbs and spices. Food Chem. 2010, 122, 987-996. 